DOI (Article): https://doi.org/10.31108/2.2020.1.19.6

УДК 159.923

\title{
Карамушка Маргарита
}

\section{ТИПИ МОЛОДІ ЗА РІВНЕМ РОЗВИТКУ ПСИХОЛОГІЧНИХ ЯКОСТЕЙ, НЕОБХІДНИХ ДЛЯ ЗДІЙСНЕННЯ СОЦІАЛЬНОЇ АКТИВНОСТІ}

\begin{abstract}
Карамушка Маргарита. Типи молоді за рівнем розвитку психологічних якостей, необхідних для здійснення соціальної активності.

Вступ. Розвиток громадянського суспільства передбачає залучення молоді до різних напрямків та форм соціальної активності. Це обумовлює необхідність вивчення різних типів соціально активної молоді (за рівнем розвитку психологічних якостей) та врахування особливостей тих типів різними сочіальними інституиіями.
\end{abstract}

Мета дослідження. Визначити типи молоді за рівнем розвитку психологічних якостей, необхідних для здійснення сочіально активності, та їх кількісну вираженість.

Методи дослідження. «Комплекс методик для вивчення психологічних характеристик соичіально активної молоді».

Результати дослідження. У результаті емпіричного дослідження визначено типи соціально активної молоді за рівнем розвитку психологічних якостей, необхідних для здійснення соціальної активності («лідери», «комунікативні», «агресивні», «уникаючі», «імпульсивні»). Описано психологічний профіль кожного із типів молоді та їх кількісну вираженість.

Висновки. Отримані дані є важливими для організащії ефективної взаємодї громадських $i$ державних організащуій з молоддю (у процесі включення ї̈ в різні соціальні проекти, благодійні акції тошьо).

Ключові слова: молодь, сочүіальна активність молоді, психологічні якості соціально активної молоді, типи соціально активно молоді.

Карамушка Маргарита. Типь молодежи по уровню развития психологических качеств, необходимых для осуществления социальной активности.

Введение. Развитие гражданского общества предполагает привлечение молодежи к различным направлениям и формам соичальной активности. Это обусловливает необходимость изучения различных типов социально активной молодежи (по уровню развития психологических качеств) и учета особенностей этих типов различными социиальными институтами.

Цель исследования. Определить типь молодежи по уровню развития психологических качеств, необходимых для осуществления сощиально активности.

Методы исследования. «Комплекс методик для изучения психологических характеристик социиально активной молодежи».

Результаты исследования. В результате эмпирического исследования определень типь социально активной молодежи по уровню развития психологических качеств, необходимых для осуществления социальной активности («лидеры», "коммуникативные», "агрессивные», «избегающие», «импульсивные»). Описан психологический профиль каждого из типов молодежи и их количественную выраженность.

Выводы. Полученные данные важны для организации эффективного взаимодействия общественных и государственных организаџий с молодежью (в прочессе включения ее в различные социальныле проекты, благотворительньле акции и т.д.).

Ключевые слова: молодежь, социальная активность молодежи, психологические качества социально активной молодежи, типь социально активной молодежи.

Вступ. Розвиток громадянського суспільства передбачає залучення молоді до різних напрямків та форм соціальної активності, сприяння розвитку їі соціального потенціалу.

Проблема соціальної активності молоді знайшла відображення в роботах різних авторів, переважно філософського та педагогічного характеру, які стосуються сутності соціальної активності та її ролі в процесі соціалізації особистості (Грабовська,\& Чолій, 2010), становлення соціальної зрілості особистості (Радул, 2011), виявів соціальної активності в різних вікових 
групах, таких, які учні (Борисова, 2011), студенти (Зіневич, 2013) та ін. Також проаналізовано роль дитячих та молодіжних об’єднань у розвитку соціальної активності, потреба дітей та молоді у співпраці з такими об'єднаннями (Беспалько, 2012; Зіневич, 2013; Чернета, 2002).

Разом із тим, слід зазначити, що психологічних досліджень з цієї проблеми є значно менше, порівняно з філософськими та педагогічними, соціологічними. Зокрема, практично відсутні дослідження, в яких визначено типи соціально активної молоді та розкрито психологічні характеристики, притаманні кожному із типів. Наявність таких наукових розробок та їх практичне впровадження може сприяти більш ефективній соціалізації самої молоді та сприяти процесам активної взаємодії з молоддю різних соціальних інституцій.

Мета дослідження: визначити типи молоді за рівнем розвитку психологічних якостей, необхідних для здійснення соціальної активності, та їх кількісну вираженість.

Методи та організація дослідження. Для дослідження психологічних якостей, необхідних для здійснення соціальної активності молоді, використовувався «Комплекс методик для вивчення психологічних характеристик соціально активної молоді».

Так, для дослідження лідерського компонента було застосовані такі методики: а) методика «Здатність до лідерства» Р.С. Немова - для оцінки загальної здатності до лідерства (Фетискін, 2002); б) методика для вивчення комунікативних та організаційних здібності (КОС2) (Райгородський, 1998) - для діагностики рівня розвитку комунікативних та організаторських здібностей.

Вивчення ціннісно-мотиваційного компонента здійснювалось за допомогою таких методики: а) методика мотиваторів соціально-психологічної активності особистості - для вивчення таких мотивів, як досягнення успіху в цілому, мотивація влади, тенденція до визнання та поваги та ін. (Фетискін, 2002); б) методика для дослідження особистісної установки «альтруїзм-егоїзм» (Райгородський, 1998).

Для вивчення емоційно-регулятивного компонента було застосовано такі методи: a) методика «Стратегії подолання стресових ситуацій (SASC)» (Водопьянова, 2009) - для вивчення основних копінг-стратегій (асертивні дії, вступ до соціального контакту, пошук соціальної підтримки, обережні дії, імпульсивні дії, уникнення, маніпулятивні (непрямі) дії, асоціальні дії, агресивні дії); б) методика для вивчення рівня соціальної фрустрованості (Райгородський, 1998).

На дослідження комунікативного компонента були спрямовані такі методики: а) методика для вивчення асертивності - для діагностики рівня впевненості у собі (Фетискін, 2002); б) методика особистісного самоконтролю М. Снайдера - для вивчення рівня комунікативного контролю (Райгородський, 1998).

Зазначені методики уможливлюють вивчення кожної із складових, які входять до основних компонентів психологічних якостей, необхідних для здійснення соціальної активності молоді.

Статистична обробка даних здійснювалась за допомогою пакета статистичних програм SSPS (версія 22). Використовувались описова статистика, кореляційний та факторний аналіз.

Вибірка дослідження. Дослідження було проведено серед молоді, яка проявляла активність у різних соціальних напрямках (учасники подій на Майдані, представники футбольного руху «Ультрас», волонтери-психологи, стипендіати програми фонду Віктора Пінчука «ЗАВТРA.UA» та ін.). Дослідження проводилось в м. Києві. У дослідженні взяло участь 152 особи.

Результати дослідження та їх обговорення. У наших попередніх публікаціях (Рудська, 2015), визначено, що психологічні якості соиіально активної молоді являють собою сукупність психологічних характеристик, які необхідні молоді для успішного виконання різних видів соціальної активності.

На основі аналізу літератури (Андрєєва, 2007; Беспалько, 2012; Борисова, 2011; Грабовська, \& Чолій, 2010; Зіневич, 2013; Радул, 2011; Чернета, 2002) та власного теоретичного аналізу проблеми нами було обгрунтовано низку психологічних якостей, які мають бути притаманні соціально активній молоді. Ці характеристики було об'єднано в такі компоненти: 
1) лідерський компонент - лідерські якості, необхідні для здійснення лідерської діяльності, яка $\epsilon$ незмінним атрибутом соціально активної молоді в сучасних умовах (загальна схильність до лідерства; організаторські та комунікативні здібності); 2) цุіннісно-мотиваційний компонент цінності, мотиви, установки та ін., які визначають спрямованість соціальної активності молоді (досягнення успіху в цілому; мотивація влади; тенденція до визнання та поваги); наявність соціально-психологічних установок «альтруїзм-егоїзм»; 3) емоційно-регулятивний компонент сукупність емоційно-регулятивних характеристик молоді, які визначають здатність молоді регулювати емоції та поведінку в різних ситуаціях соціальної активності (використання копінгстратегій як типів реакцій особистості людини з подолання стресових ситуацій - асертивні дії, вступ до соціального контакту, пошук соціальної підтримки, обережні дії, імпульсивні дії, уникнення, маніпулятивні (непрямі) дії, асоціальні дії, агресивні дії; рівень соціальної фрустрованості як ступінь задоволеності соціальними досягненнями в основних аспектах життєдіяльності особистості); 4) комунікативний компонент - сукупність комунікативних якостей молоді, які забезпечують успішне спілкування та взаємодію молоді 3 різними соціальними групами (асертивність як рівень впевненості у собі; комунікативний контроль).

Зазначимо, що психологічні якості, які входять до кожного із компонентів, можуть порізному проявлятися у різних груп молоді. I залежно від провідного напрямку у соціальній активності та індивідуальних особливостей молоді можна виділити окремі групи психологічних якостей, що будуть відображати різні структури іiі соціальної активності залежно від їх «вектору» діяльності. Для виконанні цього завдання було використано факторний аналіз.

Метод факторного аналізу - це процедура, за допомогою якої велике число змінних, що стосуються наявних спостережень, зводять до меншої кількості незалежних впливових величин, які називають факторами (Сидоренко, 2007). При цьому в один фактор поєднуються змінні, що сильно корелюють між собою, однак змінні з різних факторів слабко корелюють між собою. Таким чином, метою факторного аналізу $є$ знаходження таких комплексних факторів, які найбільш повно пояснюють спостережувані зв'язки між наявними змінними, дослідження структури взаємозв'язків змінних, ідентифікація факторів, як прихованих змінних, та вирахування значень факторів для досліджуваних, як нових, інтегральних змінних.

До основних етапів факторного аналізу належать: вирахування кореляційної матриці для всіх змінних (змінними вважаються отримані в ході побудови матриці дані шкал), вилучення факторів, обертання факторів (для отримання більш простої структури) та інтерпретація факторів (Сидоренко, 2007).

У процесі дослідження було використано факторний аналіз методом головних компонент. Тут кількість відібраних у цьому випадку факторів прирівнюється до числа власних значень, що перевершують одиницю. Метод головних компонент припускає, що повинні бути використані всі змінні, і він $є$ більш застосованим як метод зменшення даних. Тут максимізується дисперсія експериментальних даних, які пояснюються ортогональними компонентами. Обертання при цьому виконувалось методом варімакс - це ортогональне обертання, що дає найбільш просту факторну структуру. Варімакс (Varimax) - це метод, за яким відбувається мінімізація кількості змінних з високим факторним навантаженням, також він полегшує інтерпретацію факторів. Факторний аналіз дав змогу систематизувати і узагальнити наші спостереження і визначити фактори, за якими розподіляться наші шкали.

Міра вибіркової адекватності Кайзера-Мейєра-Олкіна (КМО) має значення 0,682, це більше 0,6 (задовільна адекватність), а критерій сферичності Бартлетта із значущістю в 0,000 перевіряє гіпотезу про те, що змінні в генеральній сукупності не корелюють між собою. Це означає, що ми маємо право проводити факторний аналіз на даній вибірці.

Повна пояснювальна дисперсія факторного аналізу допомагає визначити кількість факторів та вказує на кількість відсотків вибірки, яка має бути описана отриманими факторами. П’ять виділених факторів описують $62,04 \%$ усієї вибірки, що є достатньо високим показником.

Проаналізуємо дані, які отримано за допомогою факторного аналізу (табл. 1). 
Міра залученості змінних у факторах

\begin{tabular}{|l|c|c|c|c|c|}
\hline \multirow{2}{*}{ Змінні } & \multicolumn{5}{c|}{ Фактори } \\
\cline { 2 - 6 } & 1 & 2 & 3 & 4 & 5 \\
\hline Комунікативні здібності & $\mathbf{0 , 7 2 9}$ & 0,126 & $-0,174$ & 0,225 & 0,338 \\
\hline Організаторські здібності & $\mathbf{0 , 7 3 4}$ & 0,175 & 0,011 & $-0,209$ & 0,257 \\
\hline Лідерство & $\mathbf{0 , 8 2 6}$ & $-0,052$ & 0,187 & $-0,223$ & 0,027 \\
\hline Альтруїзм-егоїзм & 0,036 & 0,166 & $\mathbf{- 0 , 3 6 1}$ & $-0,294$ & $\mathbf{0 , 6 2 1}$ \\
\hline Досягнення успіху & $\mathbf{0 , 5 8 1}$ & 0,306 & $-0,025$ & $\mathbf{- 0 , 3 7 7}$ & 0,042 \\
\hline Прагнення до влади & 0,480 & 0,378 & $\mathbf{0 , 5 2 7}$ & $\mathbf{- 0 , 1 7 9}$ & $-0,159$ \\
\hline Тенденція до визнання та поваги & 0,338 & $\mathbf{0 , 7 3 2}$ & $-0,087$ & 0,073 & 0,098 \\
\hline Асертивні дії & $\mathbf{0 , 6 1 3}$ & 0,123 & $-0,016$ & 0,031 & $-\mathbf{0 , 3 0 6}$ \\
\hline Вступ у соціальний контакт & 0,103 & $\mathbf{0 , 8 3 3}$ & 0,047 & $-0,067$ & 0,138 \\
\hline Пошук соціальної підтримки & 0,036 & $\mathbf{0 , 6 9 8}$ & 0,015 & $-0,021$ & 0,025 \\
\hline Обережні дії & $-0,146$ & $\mathbf{0 , 6 2 5}$ & 0,245 & $-0,025$ & $\mathbf{- 0 , 3 6 1}$ \\
\hline Імпульсивні дії & 0,010 & $-0,008$ & 0,322 & 0,197 & $\mathbf{0 , 6 5 1}$ \\
\hline Уникнення & $\mathbf{- 0 , 2 5 8}$ & 0,217 & 0,099 & $\mathbf{0 , 7 5 3}$ & 0,151 \\
\hline Маніпулятивні дії & 0,173 & 0,093 & $\mathbf{0 , 5 9 7}$ & 0,402 & $-0,161$ \\
\hline Асоціальні дії & 0,066 & $-0,012$ & $\mathbf{0 , 8 4 8}$ & 0,135 & $-0,028$ \\
\hline Агресивні дії & $-0,125$ & 0,043 & $\mathbf{0 , 7 4 7}$ & $-0,105$ & 0,167 \\
\hline Фрустрованість & $\mathbf{- 0 , 4 3 4}$ & 0,013 & $\mathbf{0 , 2 8 1}$ & $-0,054$ & 0,047 \\
\hline Асертивність & $\mathbf{0 , 7 7 4}$ & $-0,003$ & 0,235 & $-0,014$ & $-0,056$ \\
\hline Комунікативний контроль & $-0,005$ & $\mathbf{- 0 , 1 8 2}$ & 0,015 & $\mathbf{0 , 7 1 7}$ & $-0,059$ \\
\hline
\end{tabular}

Враховуючи те, що факторний аналіз призначений зменшити кількість змінних, звести їх до меншої кількості (факторів) таким чином, що схожі між собою елементи об'єднуються в один, тим самим визначаючи деякий психологічний феномен, нами було отримано $n$ 'ять груn змінних, кожна $з$ яких описує деяке поєднання змінних, які в даному випадку можна інтерпретувати як певні типи соціально активної особистості. Найбільше значення навантаження змінної серед факторів і «окреслило» назву фактора. Важливим також відмітити, що спершу був застосований саме факторний аналіз (як групування за змінними), а не за респондентами, щоб виділити сутність психологічних феноменів для кожного типу.

До першого фактора (двополюсного) увійшли такі змінні. «Позитивний» полюс фактора включив такі найбільш виражені складові: «лідерство» $(0,826)$, «асертивність» $(0,774)$, «організаторські здібності» $(0,734)$, «комунікативні здібності» $(0,729)$, «асертивні дії» $(0,613)$, «досягнення успіху» $(0,581)$. А «негативний» полюс фактора об'єднав такі найбільш виражені змінні: «фрустрованість» $(-0,434)$, «уникнення» $(-0,258)$.

Умовно цей фактор можна назвати «лідери». Цей фактор відображає психологічні характеристики, які притаманні молодим людям, що зазвичай прагнуть до лідерства, при цьому мають високі як комунікативні, так і організаторські, здібності, проявляють асертивність та копінг-стратегію «асертивні дії», зорієнтовані на досягнення успіху. Їм менш притаманне використання копінг-стратегії «уникнення», яка не орієнтована на розв'язання проблем, з якими вони стикаються, а також соціальна фрустрованість, тобто незадоволеність життєвими досягненнями.

Другий фактор (двополюсний) представлено такими змінними. «Позитивний» полюс включає такі найбільш виражені змінні: допінг-стратегія «вступ у соціальний контакт» $(0,833)$, «тенденція до визнання та поваги» $(0,732)$, «пошук соціальної підтримки» $(0,698)$, «обережні 
дії» $(0,625)$. До «негативного» полюсу належить така найбільш представлена змінна, як «комунікативний контроль» $(-0,182)$.

Умовно цей фактор за змістом психологічних характеристик можна назвати «комунікатори». Молоді люди, яким притаманні перелічені якості, характеризуються тим, що них найважливішими є хороші комунікативні стосунки з іншими. Представники даної групи у діяльності, в першу чергу, керуються інтересами інших, швидко ідуть на поступки і можуть використовувати стратегію компромісу або ігнорування власних інтересів, щоб усім було зручно. Все це виконується обережно, очевидно, що такі люди здатні до емпатії та мають високі показники емоційного інтелекту, їм легко заводити нових друзів та вступати у розмову. Основними причинами такої поведінки може бути залежність від думки оточуючих, бажання соціальної підтримки від них, оцінки власної роботи, що, у свою чергу, може свідчити про нестабільну самооцінку, частіше занижену. Вони можуть бути підлеглими, які старанно виконують роботу, або тими, хто вдало може проводити перемови. Негативними сторонами такого типу $\epsilon$ залежність, що може відхиляти таку особистість від поставленої мети, спричинювати гальмування розвитку групи, неможливість відстоювати власну думку.

Так, як і попередні два фактори, третій фактор є двополюсним. «Позитивний» полюс включає такі найбільш виражені змінні: «асоціальні дії» $(0,848)$, «агресивні дії» $(0,747)$, «маніпулятивні дії» $(0,597)$, «прагнення до влади» $(0,527)$. «Негативний» полюс представлений таким показником, як «альтруїм-егоїзм» $(-0,361)$.

За сукупністю змінних, які представлені в його структурі, такий фактор можна умовно назвати «агресивні». Тобто мова йде про молодих людей, які зазвичай агресивно досягають свого, їм важко працювати в команді, але вони досить добре вміють досягати поставленої мети, хоча i не завжди гуманними способами. Представники цього типу $\epsilon$ сильними та самовпевненими, вони досить стрімко намагаються досягти керівних посад, для чого можуть маніпулювати іншими, створювати ситуації, щоб покращити думку про себе інших. Зазвичай такі люди не дуже товариськими, вони є егоїстичними, в першу чергу думають лише про власні інтереси. Такі люди можуть займатися соціальною активністю задля досягнення власних цілей, самоствердження та самореалізації, при цьому допомога іншим або соціально бажана поведінка відходять на другий план.

До складу четвертого фактора (двополюсного) увійшли наступні складові. «Позитивний» полюс представлено такими змінними: «уникнення» (0753), «комунікативний контроль» (0717). На протилежному, «негативному», полюсі перебувають такі показники: «досягнення успіху» $(-0.377)$, «прагнення до влади» $(-0,179)$.

За змістом змінних, які входять у цей фактор, таких представників можна назвати «уникаючі». Для молодих людей, яким притаманні названі характеристики, характерним є те, що вони намагаються уникати будь-якого контакту. Це можуть бути інтроверти, які полюбляють самостійно працювати. Важливим при цьому $є$ те, що саме у цьому факторі спостерігається високий рівень «уникнення». Разом із тим, слід брати до уваги, що це теж група осіб, що займаються соціальною активністю, намагаються досягати цілей у своїй діяльності. Поряд 3 цим вони мають низькі показники за мотивом досягнення успіху, що означає, що в діяльності у них превалює інша стратегія - уникнення невдач, вона також має на меті досягнення цілі, але шляхом уникнення ситуацій, де результат діяльності залежить від особистості. Такі люди часто не можуть адекватно оцінити ситуацію, але вони оцінюють власні здібності і знають випадки, коли можуть отримати поразку і намагаються уникати їх. I якщо ж така людина в ситуації досягнення має неуспіх, то вона може пояснити його зовнішніми чинниками або ж нереалістично завищеним чи заниженим рівнем завдання відповідно до власних здібностей, таким чином, що власні дії не могли б змінити хід ситуації. Ці люди дуже вдало контролюють себе і власні слова. Вони можуть шукати підтримки в оточуючих, але не у всіх, а лише у перевірених осіб, тих, кого вважають своїми друзями. Вони також прагнуть до влади і можуть цього досягти, але шляхом уникнення негараздів. Вони не йдуть у справах на ризик, а роблять лише те, у чому впевнені.

П'ятий фактор (двополюсний) характеризується тим, що він включає такі характеристики. «Позитивний» полюс представлено такими змінними: «імпульсивні дії» 
(0,651), «альтруїзм-егоїзм» $(0,621)$. До «негативного» полюсу віднесено: «обережні дії» $(-0,361)$ та «асертивні дії» $(-0,306)$.

За своїм змістом представників даної групи можна віднести до типу «імпульсивні». Це молоді люди, які імпульсивні за своєю природою, які швидше діють, ніж думають, можуть надихати інших, при тому, що діяльність їх самих не завжди є організованою і самостійною, а тому може не приносити вдалого результату. Цей тип осіб найбільше вирізняє імпульсивність та альтруїзм. При цьому вони не вміють себе поводитися обережно і коректно стосовно оточуючих, можуть вперто доводити свою точку зору і емоційно реагувати на ії нівелювання або негативні висловлювання (дії) щодо себе чи своєї справи, при цьому не проявляючи асертивність. Хоча у таких осіб є досить сильне бажання допомагати іншим, ставити їх інтереси вище за свої, очевидно, така стратегія не приносить їм бажаного задоволення від праці, заохочення чи визнання.

Також було проаналізовано кількісну вираженість визначених типів молоді. Серед усієї вибірки до групи «лідерів» потрапило 35,0\% опитаних, «комунікаторів» - 23,0\%, «агресорів»$17,0 \%$, «уникаючих» - 17,0\%, «імпульсивних» - 10,0\%. Це свідчить про те, що до типу соціально активної молоді «лідери», який, до певної міри, $є$ «ідеальним», належить трохи більше третини опитаних, а решта не є такими.

Отже, слід брати до уваги, що молоді люди, які належить до решти чотирьох груп, не $є$ «лідерами», однак вони також є соціально активними і проявляють себе в різних напрямках соціальної активності (науковій, патріотичній, спортивній, благодійній тощо), реалізуючи свій стиль соціальної активності. Тому в процесі взаємодії з різними категоріями соціально активної молоді слід враховувати психологічні особливості кожної із груп, як їх позитивні характеристики, так і обмеження.

Отже, в процесі дослідження було визначено типи соціально активної молоді за рівнем розвитку психологічних якостей, необхідних для здійснення соціальної активності, та переважаючими у них компонентами («лідери», «комунікативні», «агресивні», «уникаючі», «імпульсивні»). Описано психологічний профіль кожної із груп та їх кількісну вираженість.

Висновки. Отримані дані стосовно наявності серед соціально активної молоді різних типів (за рівнем розвитку психологічних якостей) $є$ важливими для організації ефективної взаємодії громадських і державних організацій з молоддю у процесі включення іiі в різні соціальні проекти, благодійні акції тощо, а також для запобігання та подолання існуючих соціальних стереотипів про те, що в соціальну активність можуть бути включені лише молоді люди, які належать до типу «лідери».

\section{Література}

1. Андреева, Ю. (2007). В фокусе - молодежный активизм. Ульяновск: ИЦ Ульянов. гос. ун-та.

2. Безпалько, О. В. (2012). Розвиток соціальної активності особистості у дитячому об'єднанні. Вісник психології $i$ педагогіки : зб. наук. пр., 8, 3-16.

3. Борисова, Т. С. (2011). Активность и инициативность как основа формирования социальной ответственности учащейся молодежи. Вестник ТГПУ, 1(103),131-136.

4. Водопьянова, Н. Э. (2009). Психодиагностика стресса. Санкт-Петербург.

5. Грабовська, С. Л., \& Чолій, С. Л. (2010). Соціальна активність в процесі соціалізації особистості: Зб. наук. пр. Інституту психології імені Г. С. Костюка АПН України ; С. Д. Максименко (Ред.), ХІІ (1), 171-181.

6. Зиневич, О. А. (2013). Потребность студентов в создании новых молодежных объединений. Инновационное развитие и кадровый потенциал молодежной и социальной сферы : м-лы Междун. науч.-практ. конф. (СанктПетербург, 21-23 ноября 2013 г.), Г.В. Ковалева (Ред.). Санкт-Петербург: ФГБОУВПО «СПГУТД», $116-117$.

7. Райгородский, Д. Я. (1998). Практическая психодиагностика: Методики и тесть. (Учеб. пособие). Самара: ИД «Бахрах».

8. Радул, В. В. (2011). Соціальна активність у структурі сочіальної зрілості (теоретико-методологічний аспект). (Монографія). Кіровоград: Імекс-ЛТД.

9. Рудська, М. І. (Карамушка, М. І.) (2015) Комплекс методик для дослідження психологічних особливостей соціально активної молоді. Актуальні проблеми психології : збірник наукових праць Інституту психології імені Г. С. Костюка НАПН України, 1 (43), 125-129.

10. Рудська, М. І. (Карамушка, М. І.) (2015). Проблеми дослідження соціальної активності молоді. Теоретичні $i$ прикладні проблеми психології : збірник наукових праць Східноукраїнського національного університету імені Володимира Даля, 2 (38). 269-278. 
11. Сидоренко, Е. В. (2007). Методы математической обработки в психологии. Санкт-Петербург: ООО «Речь».

12. Фетискин, Н. П., Козлов, В. В., \& Мануйлов, Г. М.(2002). Социально-психологическая диагностика развития личности и малых групп. Москва: Изд-во Ин-та психотерапии.

13. Чернета, С. Ю. (2002). Самодіяльні молодіжні об’єднання як фактор формування соціальної активності особистості. Теоретико-методичні проблеми виховання дітей та учнівської молоді: зб. наук. праць (У 2 кн., кн. 2), $118-122$.

\section{References}

1. Andreeva, Ju. (2007). V fokuse - molodezhnyj aktivizm [The focus is on youth activism]. Uljanovsk: IC Ul'janov. gos. un-ta [in Russian].

2. Bezpalko, O. V. (2012) Rozvytok sotsialnoi aktyvnosti osobystosti u dytiachomu obiednanni [Development of social activity of the individual in the children's association]. Visnyk psykholohii i pedahohiky : zb. nauk. pr., 8, 3-16 [in Ukrainian].

3. Borisova, T. S. (2011). Aktivnost i iniciativnost kak osnova formirovanija socialnoj otvetstvennosti uchashhejsja molodezhi [Activity and initiative as a basis for the formation of student social responsibility]. Vestnik TGPU, 1(103),131136 [in Russian].

4. Vodopjanova, N. Je. (2009). Psihodiagnostika stressa [Psychodiagnostics of stress]. Sankt-Peterburg.

5. Hrabovska, S. L., \& Cholii S. L. (2010) Sotsialna aktyvnist v protsesi sotsializatsii osobystosti [Social activity in the process of socialization of the individual]. Zb. nauk. pr. Instytutu psykholohii imeni H.S. Kostiuka APN Ukrainy ; S. D. Maksymenko (Red.), KhII (1), 171-181 [in Ukrainian].

6. Zinevich, O. A. (2013) Potrebnost studentov v sozdanii novyh molodezhnyh objedinenij [Students need of new youth associations]. Innovacionnoe razvitie $i$ kadrovyj potencial molodezhnoj $i$ socialnoj sfery : m-ly Mezhdun. nauch.-prakt. konf. (Sankt-Peterburg, 21-23 nojabrja 2013 g.), G. V. Kovaleva (Red.). Sankt-Peterburg: FGBOUVPO «SPGUTD», 116117 [in Russian].

7. Rajgorodskij, D. Ja. (1998). Prakticheskaja psihodiagnostika: Metodiki i testy [Practical psychodiagnostics: instruments and tests]. (Ucheb. posobie). Samara: ID «Bahrah» [in Russian].

8. Radul ,V. V.(2011) Sotsialna aktyvnist u strukturi sotsialnoi zrilosti (teoretyko-metodolohichnyi aspekt) [Social activity in the structure of social maturity (theoretical and methodological aspect)]. (Monohrafiia). Kirovohrad: Imeks-LTD [in Ukrainian].

9. Rudska, M. I. (Karamushka, M. I.). (2015) Kompleks metodyk dlia doslidzhennia psykholohichnykh osoblyvostei sotsialno aktyvnoi molodi [A set of instruments for studying psychological characteristics of socially active youth]. Aktualni problemy psykholohii : zbirnyk naukovykh prats Instytutu psykholohii imeni H.S. Kostiuka NAPN Ukrainy, 1 (43), 125-129[in Ukrainian].

10. Rudska, M. I. (Karamushka, M. I.).(2015). Problemy doslidzhennia sotsialnoi aktyvnosti molodi [Problems of research into youth social activity]. Teoretychni i prykladni problemy psykholohii : zbirnyk naukovykh prats Skhidnoukrainskoho natsionalnoho universytetu imeni Volodymyra Dalia, 2 (38). 269-278 [in Ukrainian].

11. Sidorenko, E. V. (2007). Metody matematicheskoj obrabotki v psihologii [Mathematical methods in psychology]. Sankt-Peteburg: OOO «Rech» [in Russian].

12. Fetiskin, N. P., Kozlov, V. V., \& Manujlov, G. M.(2002). Socialno-psihologicheskaja diagnostika razvitija lichnosti $i$ malyh grupp [Social-psychological assessment of personality and small group development]. Moskva: Izd-vo In-ta psihoterapii [in Russian].

13. Cherneta, S. Yu. (2002). Samodiialni molodizhni obiednannia yak faktor formuvannia sotsialnoi aktyvnosti osobystosti [Independent youth associations as a factor in shaping social activityof the individual]. Teoretyko-metodychni problemy vykhovannia ditei ta uchnivskoi molodi: zb. nauk. prats (U 2 kn., kn. 2), 118-122 [in Ukrainian].

\section{Karamushka, Marharyta. Categories of youth according to the levels of development of their social activity-relevant psychological qualities. \\ Introduction. The development of civil society is based, in particular, on young people's involvement in} various social activities. This necessitates the study of different categories of socially active youth in relation to the levels of development of their psychological qualities to be taken into account by different social institutions.

The aim of the study: to determine the categories of young people in relation to the levels of development of their social activity-relevant psychological qualities.

Methods. A set of methods for studying psychological characteristics of socially active youth.

Results. Socially active youth has been classified according to the levels of development of their social activity-relevant psychological qualities and their main components ("leaders", "communicators", "aggressive", "avoiding", "impulsive"). The author describes the psychological profile of each category of youth and its percentage of the sample.

Conclusions. The obtained data can be helpful in the organization of effective interaction of public and state organizations with young people through their inclusion in various social projects, charitable actions, etc., as well as for challenging social stereotypes about leaders as the only category of socially active young people. 
Key words: youth, youth social activity, psychological qualities of socially active youth, types of socially active youth.

\title{
Відомості про автора
}

Карамуша Маргарита Ігорівна, аспірантка факультету психології Київського національного університету імені Тараса Шевченка, м. Київ, Україна.

Karamushka, Marharyta Ihorivna, PhD student, dept. of psychology, Taras Shevchenko National University of Kyiv, Kyiv, Ukraine.

E-mail: mrudska@gmail.com

ORCID ID:https://orcid.org/0000-0003-4421-8178

Отримано 01 грудня 2019 p.

Рецензовано 05 січня $2020 \mathrm{p}$.

Прийнято 27 січня 2020 p.

DOI (Article): https://doi.org/10.31108/2.2020.1.19.7

УДК 159.922.7-053.6:316.658.4

Клибанівська Тетяна, Попова Олена

\section{ОСОБЛИВОСТІ СТАВЛЕННЯ ДІТЕЙ ПІДЛІТКОВОГО ВІКУ ДО СОЦІАЛЬНОӦ} РЕКЛАМИ

\author{
Клибанівська Тетяна, Попова Олена. Особливості ставлення дітей підліткового віку до \\ соціальної реклами. \\ Вступ. У статті здійснено аналіз теоретичних аспектів сприйняття соиіальної реклами дітьми
} підліткового віку. Вказано значення актуальності дослідження ролі реклами у формуванні світогляду підлітків.

Метою дослідження є визначення особливостей ставлення підлітків до соиіальної реклами, ї̈ впливу на формування ціннісно-світоглядних позицій у підлітковому віщі $і$ на розвиток позитивних тендениій у світосприйнятті.

У дослідженні використано метод анкетування.

Результати дослідження. Виявлено суттєвий вплив соиіальної реклами на формування світогляду у підлітків.

Висновки. Стверджено, щяо соціальна реклама є ефективним засобом психологічного впливу на підлітків.

Ключові слова: реклама, соціальна реклама, рекламний вплив, підлітки, ціннісні орієнтащії, світосприйняття, світогляд, свідомість підлітків.

Клебановкая Татьяна, Попова Елена. Особенности отночения детей подросткового возраста к социальной рекламе.

Введение. В статье проведен анализ теоретических аспектов восприятия социальной рекламы детьми подросткового возраста. Указано значение актуальности исследования роли рекламы в формировании мировоззрения подростков.

Целью исследования является определение особенностей отношения подростков к соииальной рекламе, ее влияния на формирование иенностно-мировоззренческих позиций в подростковом возрасте и на развитие позитивних тенденций в мировосприятии.

В исследовании использован метод анкетирования.

Результаты исследования. Выявлено существенное влияние сочиальной рекламы на формирование мировоззрения у подростков. 